International Journal of Dental Research, 8(2) (2021) 24-41
International Journal of Dental Research
SPC
Website: www.sciencepubco.com/index.php/IJDR
Research paper

\title{
Failures and reoperation in fixed prosthesis -Systematic Review-
}

\author{
CHAFII Amine ${ }^{l}$, MOUHIBI Abdallah ${ }^{2 *}$, ANDOH Abderrhman ${ }^{3}$ \\ ${ }^{1}$ Professeur in fixed Prosthetic departement \\ ${ }^{2}$ Specialist dentist in fixed Prosthetic \\ ${ }^{3}$ Head of derpartement of fixed Prosthetic \\ *Corresponding author E-mail: abdallah.mouhibi-etu@etu.univh2c.ma \\ Author Adress: 11 Alley lantanas Ainsebâa Casablanca Morocco PC: 20580
}

\begin{abstract}
Our systematic review is made in view of the absence of studies dealing with failures and reoperations which encompassed all types of dento-supported fixed prosthetic restorations and aims to study prosthetic failures that could be encountered in fixed dento-supported prosthesis and the solutions to remedy

Over the past two centuries, considerable progress has been made under the leadership of many scientists who have developed materials and techniques, with the aim of improving the quality of care and improving ergonomics.

In short, in fixed prosthesis, failures have particularly serious consequences and can occur at all levels involved for these restorations. They can happen at any time.

This is how we were able to note the influence of certaine variable on the success and durability of the treatments, which did not depend only on the skill and precision used during prosthetic development, such as the location, arch, preparation design, number of abutments, type of material used, bonding material, surface treatment and technologies used.

So the choice of restorative materials was a decisive factor that had to be the result of a careful study of the different materials available depending on the clinical situation, in order to increase their longevity and therefore reduce the risk of failure.
\end{abstract}

Keywords: Failure, Reoperation, fixed prosthesis, prosthodontic, systematic review, restoration.

\section{Introduction}

Over the past two centuries, considerable progress has been made under the leadership of many scientists who have developed materials and techniques, with the aim of improving the quality of care and improving ergonomics. (11).

These treatments represent a financial burden for patients and health systems, especially if they fail or must be redone for biological reasons such as: secondary caries, endodontic and periodontal problems, fracture of abutment teeth ... or techniques: fracture of restorations or covering materials, loosening ... or even aesthetics, which requires a good diagnosis followed by a well-thought-out treatment plan to be able to obtain a good prosthetic integration (1).

Despite the respect of the different stages of development, no practitioner can claim to be immune from prosthetic failure. This is valid regardless of his experience, rigor or skill. And so he will face different forms of complications, whether of periodontal, prosthetic, endodontic, aesthetic or functional origin. And any failure requires a reoperation, but every reoperation does not always mean the removal of the prosthetic element but it can be a repair of the prosthesis in the mouth. For this, the therapeutic decision will be made after a careful and very precise clinical examination while trying to meet the patient's wishes.

Our systematic review is made in view of the absence of studies dealing with failures and reoperations which encompassed all types of dento-supported fixed prosthetic restorations and aims to study prosthetic failures that could be encountered in fixed dento-supported prosthesis and the solutions to remedy it.

\section{Materiel \& methods}

This is a systematic review carried out according to PRISMA criteria (Preferred Reporting Items for Systematic reviews and Meta Analysis) (34) and the Guide of Cochrane Diagnostic Test Accuracy Protocol and reviews (58), registered in the PROSPERO database under the number : 160571.

A documentary search was carried out on 3 databases: MEDLINE, EMBASE, Cochrane Library, the keywords used: Denture, Partial, Fixed;

Denture, Partial, Fixed, Resin-Bonded; Prosthodontics; Equipment Failure; Equipment Failure Analysis; Dental Restoration Failure; Retreatment. 
Articles meeting the following criteria were included: published between 10/01/2009 and 10/01/2019, Relating to living humans, Metaanalyzes and systematic reviews, Randomized controlled clinical trials and non-randomized clinical trials, Comparative clinical studies , Without language restriction or country of study, Studies for which the follow-up was at least 3 years, Studies for which the number of patients was at least 10, The patients were examined clinically during the follow-up period, Studies which related to: dento-supported fixed prosthetic restorations providing information on failures, complications, materials, production and reoperation techniques.

Exclusion criteria: In vitro studies, Case studies, Retrospective studies, Studies funded by manufacturers (conflict of interest), Preliminary or provisional studies, Studies relating to: fixed implant-supported prosthetic restorations, pedodontic caps.

The analysis is carried out according to the reading grids proposed by R. SALMI (47), according to the types of studies selected, in order to be able to criticize them in a relevant way and in order to keep only the work of sufficient methodological quality

The selection of studies was conducted by two readers (O.L. and A.J) independently, and any disagreements about the following process were resolved by discussion before proceeding to the next step.

The realization of the first sorting was based on the titles of the studies and made it possible to eliminate any study outside a discipline, which belonged to the discipline but which were outside the subject or which did not meet the following two inclusion criteria: types of 'articles and study on living humans.

For the second level of triage, the same readers read the abstracts in order to eliminate studies that did not meet the inclusion and noninclusion criteria cited above as well as those that did not meet the objective of our review.

As for the third sorting, it consisted of a critical reading of the full texts by applying R. SALMI's grids in order to choose only the studies deemed to be of acceptable methodological quality.

And so the final number of validated publications represents a database for systematic analysis that will be explored in the results and discussions section. Les examinateurs (O.L et A.J) ont élaboré des tableaux qui ont permis de classer les données collectées à partir des articles retenus.

The data mining was conducted by these readers independently, with formal processes of discussion and consensus building in the event of disagreement, to minimize subjectivity during the multiple stages of completion.

Any reconstruction that required replacement, repair, recementation or re-gluing, due to a biological or technical complication, has been defined in this review as failure. On the other hand, a mild complication such as minor sintering of the ceramic or dentinal hypersensitivity that goes away might not be considered a failure.

Because the information concerning the abandonment of the studies selected was not detailed according to each type of restoration or material; we have not taken abandonment into consideration in order to limit the risk of bias.

The biases were assessed using the tool recommended by the online guide of "Cochrane Handbook for Systematic Reviews of Interventions" which provides advice to authors for the preparation of their systematic reviews, this guide has been adapted and updated by Higgins and his associates in 2019 (57).

The biases that were included in this review are as follows:

a) Selection bias: is linked to the inclusion criteria of the studied population which had to respect the following rules:

- The subjects included in the study had to constitute a representative group of the target population.

- The process of selection by randomization should be described in a clear and orderly manner.

- The participants had to have the same basic characteristics.

b) Attrition bias, information bias, notification bias, performance bias, detection bias, and other biases

For each article, the estimate of risk of bias was broken down into 3 categories.

The judgment criteria for estimating the risk for each bias were mentioned in the qualitative risk of bias assessment tables

The clinical research was carried out according to the following diagrams and all the characteristics of these studies have been described in Table I.

We determined the risk of bias of the articles using the Guidelines. (57) (Table II).

It is noted that the blinded procedure for patients and practitioners was difficult to perform in this type of study.

The failure and its different forms were studied and compared according to the type of prosthetic restoration and its material of manufacture It was decided not to group the different types of all-ceramic restorations into a single group in the review due to the difference in their composition Table III and Table IV.

Some studies did not specify the failures found according to their type, so we grouped them together in the "other not specified" box in Table IV. 


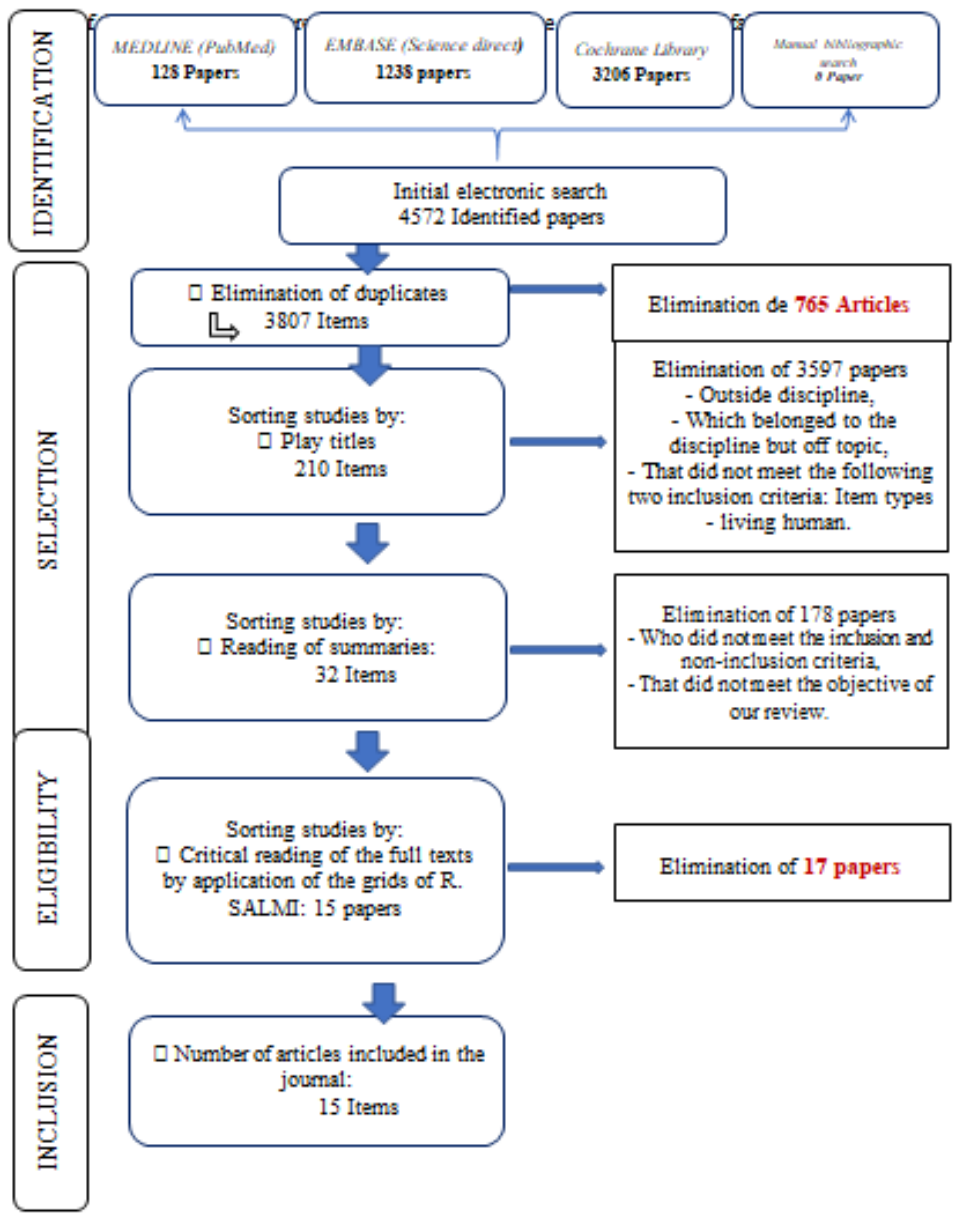

Fig. 1: Flow Diagram According to PRISMA Format.

\begin{tabular}{|c|c|c|c|c|c|c|c|c|c|c|c|}
\hline Title & Author & $\begin{array}{l}\text { Year of } \\
\text { Publica- } \\
\text { tion }\end{array}$ & Country & $\begin{array}{l}\text { Type of } \\
\text { study }\end{array}$ & $\begin{array}{l}\begin{array}{l}\text { Suivi } \\
\text { moyen } \\
\text { (ans) }\end{array} \\
\end{array}$ & $\begin{array}{l}\text { No. de } \\
\text { pa- } \\
\text { tient }\end{array}$ & $\begin{array}{l}\text { Age } \\
\text { moyen } \\
\text { (ans) } \\
\end{array}$ & $\begin{array}{l}\text { No. of } \\
\text { restaura- } \\
\text { tions } \\
\end{array}$ & $\begin{array}{l}\text { Type of re- } \\
\text { construc- } \\
\text { tions }\end{array}$ & $\begin{array}{l}\text { Aban- } \\
\text { dons } \\
(\mathrm{P} / \mathrm{R}) \\
\end{array}$ & $\begin{array}{l}\text { Localisa- } \\
\text { tion }\end{array}$ \\
\hline $\begin{array}{l}\text { Random- } \\
\text { ized clinical } \\
\text { trial on indi- } \\
\text { rect resin } \\
\text { composite } \\
\text { and ceramic } \\
\text { laminate ve- } \\
\text { neers: Up to } \\
\text { 10-year } \\
\text { findings. }\end{array}$ & $\begin{array}{l}\text { Gresnigt } \\
\text { MMM. et al. } \\
(23)\end{array}$ & 2019 & $\begin{array}{l}\text { Pays } \\
\text { bas }\end{array}$ & $\begin{array}{l}\text { Essai } \\
\text { clinique } \\
\text { contrôlé } \\
\text { randomisé }\end{array}$ & 8.08 & 11 & 54.5 & 48 & $\begin{array}{l}\text { Facettes : } \\
\text { - en résine } \\
\text { composite } \\
\text { indirecte = } \\
24 \\
\text { - céramique } \\
\text { stratifiée } \\
=24\end{array}$ & $0 / 0$ & $\begin{array}{l}\text { Maxil- } \\
\text { laire An- } \\
\text { térieur }\end{array}$ \\
\hline $\begin{array}{l}\text { CAD/CAM } \\
\text { or conven- } \\
\text { tional ce- } \\
\text { ramic mate- } \\
\text { rials restora- } \\
\text { tions lon- } \\
\text { gevity: a } \\
\text { systematic } \\
\text { review and } \\
\text { meta-analy- }\end{array}$ & $\begin{array}{l}\text { Rodrigues SB. } \\
\text { et al. (42) }\end{array}$ & 2019 & Brésil & $\begin{array}{l}\text { Revue sys- } \\
\text { tématique et } \\
\text { méta-ana- } \\
\text { lyse }\end{array}$ & 4.34 & 957 & 43.6 & 1223 & $\begin{array}{l}\text { Couronnes } \\
\text { unitaires et } \\
\text { bridges } \\
\text { scellés en } \\
\text { céramique } \\
\text { technique } \\
\text { convention- } \\
\text { nelle ou } \\
\text { CAD/CAM }\end{array}$ & n.r/453 & $\begin{array}{l}\text { Antérieur } \\
\text { postéri- } \\
\text { eur }\end{array}$ \\
\hline $\begin{array}{l}\text { 10-year ran- } \\
\text { domized } \\
\text { trial (RCT) } \\
\text { of zirconia- } \\
\text { ceramic and } \\
\text { metal-ce- } \\
\text { ramic fixed } \\
\text { dental pros- } \\
\text { theses. }\end{array}$ & $\begin{array}{l}\text { Sailer I. et al. } \\
(43)\end{array}$ & 2018 & Suisse & $\begin{array}{l}\text { Essai } \\
\text { clinique } \\
\text { contrôlé } \\
\text { randomisé }\end{array}$ & 10.15 & 58 & 60.9 & 76 & $\begin{array}{l}\text { Bridges de } \\
3 \text { à } 5 \text { uni- } \\
\text { tés : } \\
\text { - Céramo- } \\
\text { céramiques } \\
\text { à base de } \\
\text { zircone = } \\
40 \\
\text { - Céramo- } \\
\text { métalliques } \\
=36\end{array}$ & $13 / 17$ & $\begin{array}{l}\text { Postéri- } \\
\text { eur }\end{array}$ \\
\hline
\end{tabular}




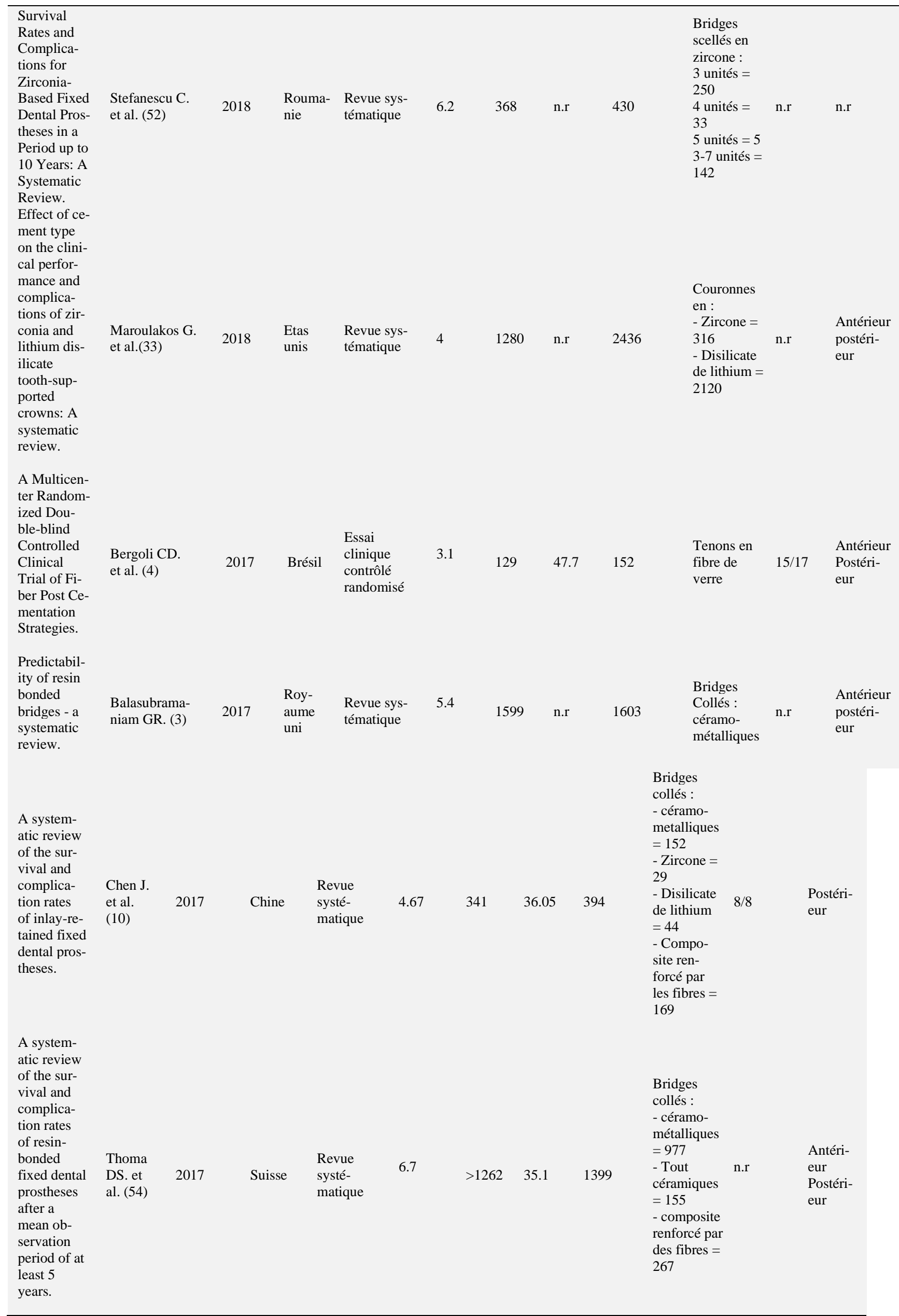




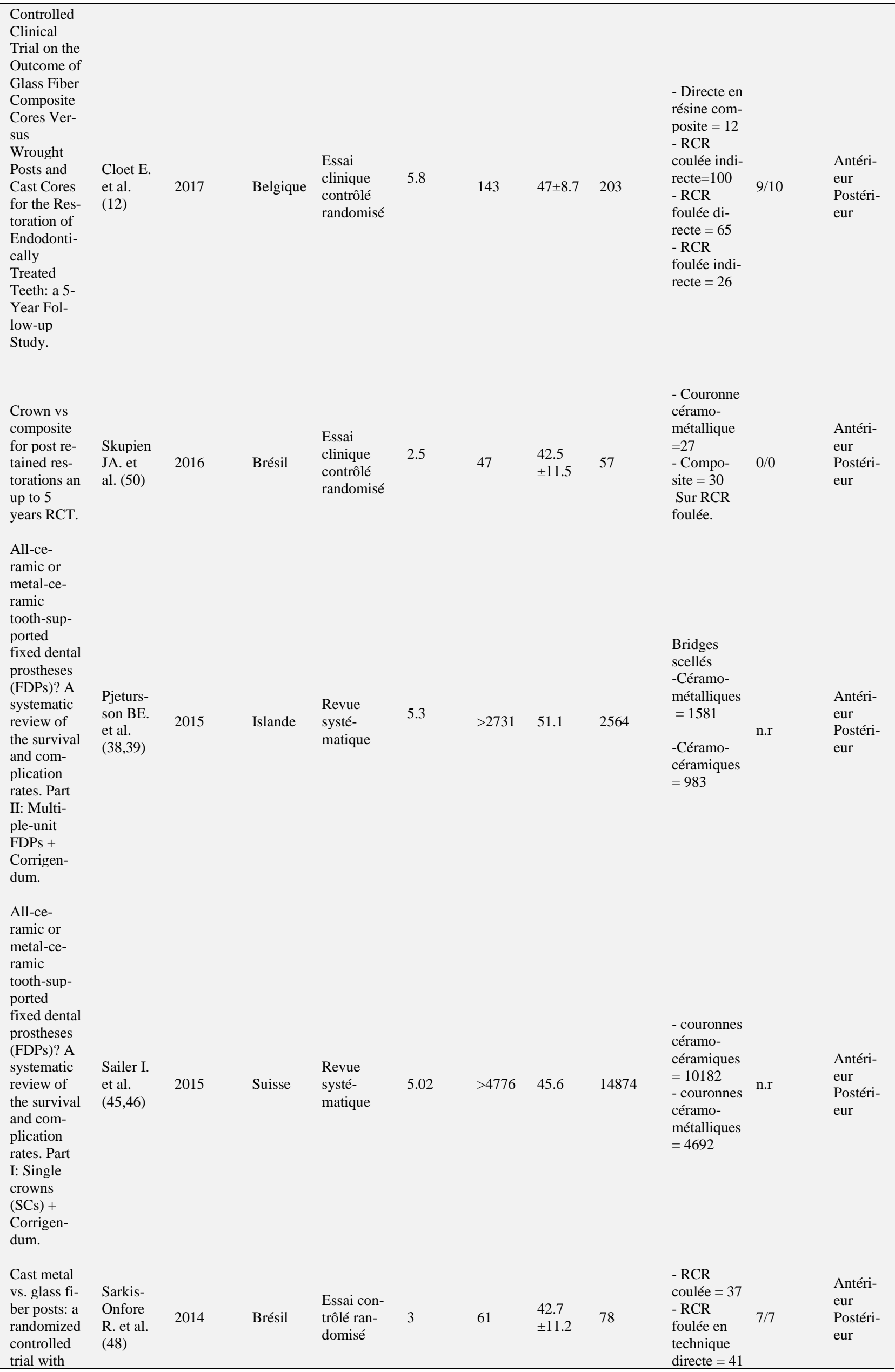




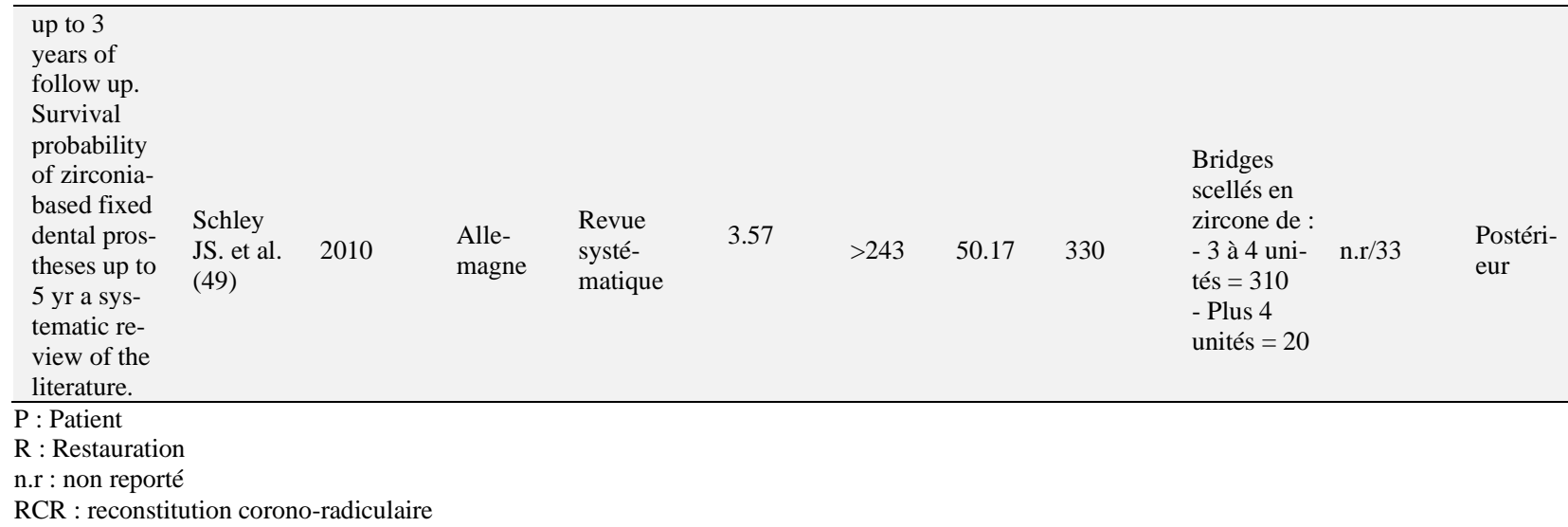

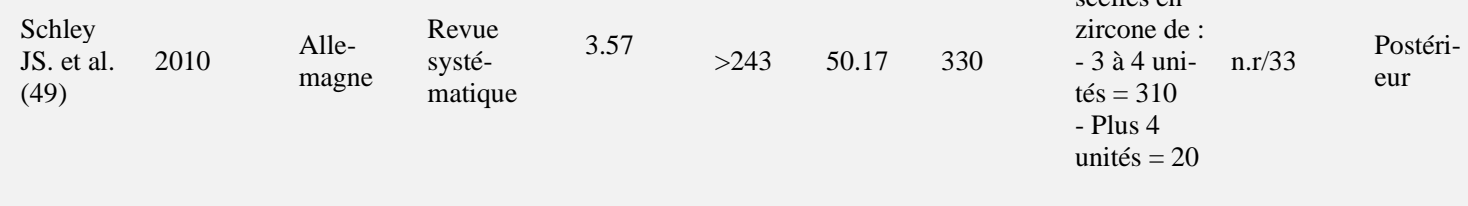

Bridges

scellés en

Table 2: Qualitative Risk of Bias Assessment of Included Randomized Controlled Trials

\begin{tabular}{|c|c|c|c|c|c|c|c|}
\hline Author & $\begin{array}{l}\text { Biais de sélec- } \\
\text { tion }\end{array}$ & $\begin{array}{l}\text { Biais } \\
\text { d'attrition }\end{array}$ & $\begin{array}{l}\text { Biais d'informa- } \\
\text { tion }\end{array}$ & $\begin{array}{l}\text { Biais de notifica- } \\
\text { tion }\end{array}$ & $\begin{array}{l}\text { Biais de détec- } \\
\text { tion }\end{array}$ & $\begin{array}{l}\text { Autre } \\
\text { biais }\end{array}$ & $\begin{array}{l}\text { Risque de } \\
\text { biais }\end{array}$ \\
\hline $\begin{array}{l}\text { Gresnigt MMM. et al. } \\
\text { (23) }\end{array}$ & Faible & Faible & Faible & Faible & Faible & Faible & Minime \\
\hline Sailer I. et al. (43) & Faible & Elevé & Faible & Faible & Intermédiaire & Faible & Elevé \\
\hline Bergoli CD. et al. (4) & Faible & $\begin{array}{l}\text { Intermé- } \\
\text { diaire }\end{array}$ & Intermédiaire & Faible & Faible & Faible & Incertain \\
\hline Cloet E. et al. (12) & Intermédiaire & Faible & Intermédiaire & Faible & Faible & Faible & Incertain \\
\hline Skupien JA. et al. (50) & Faible & Faible & Faible & Faible & Faible & Faible & Minime \\
\hline $\begin{array}{l}\text { Sarkis-Onfore R et al. } \\
(48)\end{array}$ & Faible & $\begin{array}{l}\text { Intermé- } \\
\text { diaire }\end{array}$ & Faible & Faible & Faible & Faible & Incertain \\
\hline
\end{tabular}

Table 3: Failure Rate According to the Type of Prosthetic Restoration and Material of Manufacture:

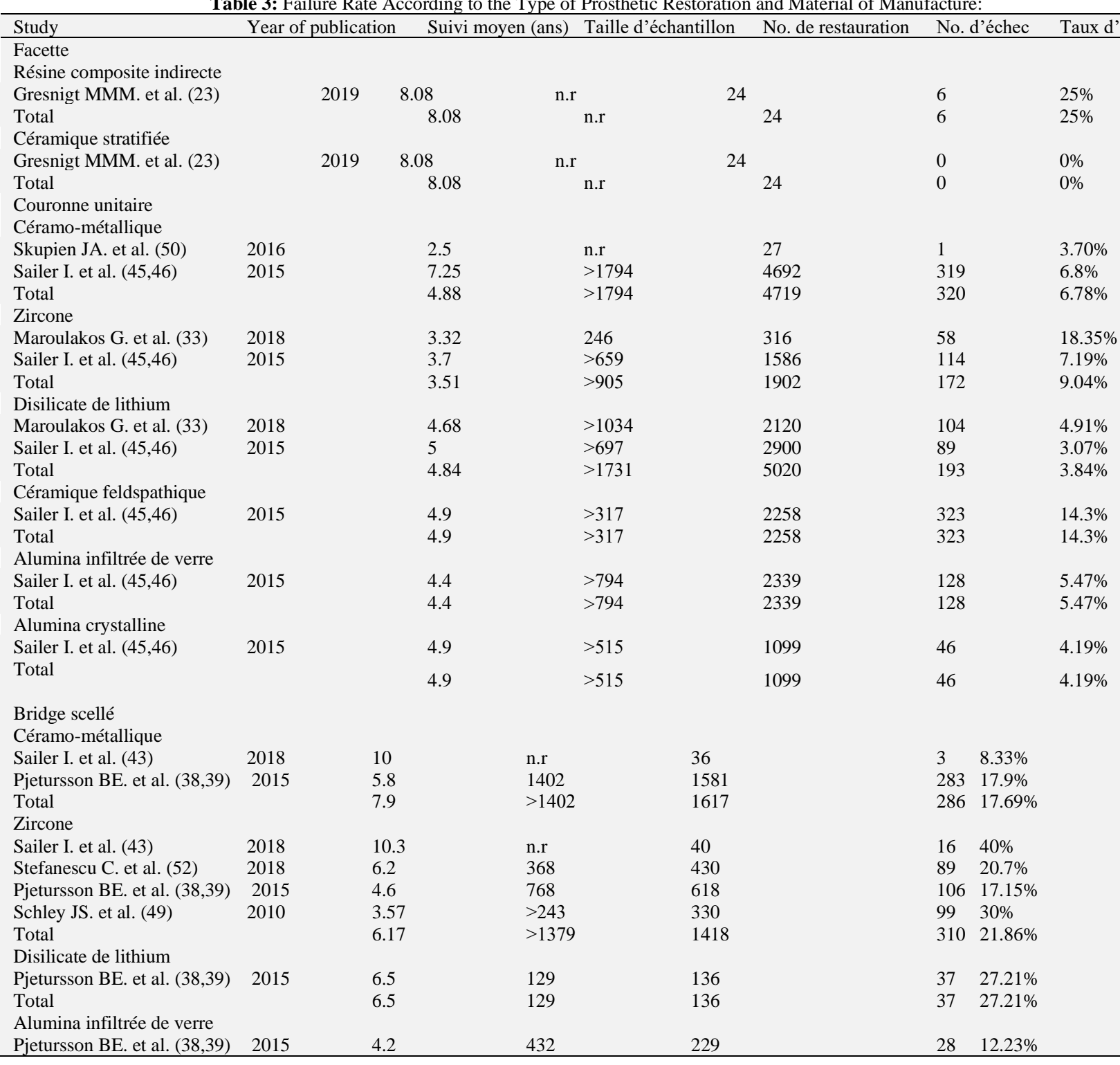




\begin{tabular}{|c|c|c|c|c|c|c|c|}
\hline Total & \multicolumn{2}{|r|}{4.2} & 432 & \multicolumn{2}{|c|}{229} & \multicolumn{2}{|c|}{$28 \quad 12.23 \%$} \\
\hline \multicolumn{8}{|l|}{ Bridge collé } \\
\hline \multicolumn{8}{|l|}{ Céramo-métallique } \\
\hline Balasubramaniam GR. (3) & 20175.4 & & 1599 & 1603 & 241 & & $15.03 \%$ \\
\hline Chen J. et al. (10) & 20174.8 & & 116 & 152 & 56 & & $36.84 \%$ \\
\hline Thoma DS. et al. (54) & 20177.3 & & 766 & 977 & 107 & & $10.95 \%$ \\
\hline Total & 5.83 & & 2481 & 2732 & 404 & & $14.79 \%$ \\
\hline \multicolumn{8}{|l|}{ Zircone } \\
\hline Chen J. et al. (10) & 20175.4 & & 30 & 29 & 9 & & $31.03 \%$ \\
\hline Thoma DS. et al. (54) & 20175.2 & & 79 & 68 & 0 & & $0 \%$ \\
\hline Total & 5.3 & & 109 & 97 & 9 & & $9.28 \%$ \\
\hline \multicolumn{8}{|l|}{ Disilicate de lithium } \\
\hline Chen J. et al. (10) & 20175.8 & & 42 & 44 & 40 & & $90.91 \%$ \\
\hline Thoma DS. et al. (54) & 20176 & & 40 & 49 & 2 & & $4.08 \%$ \\
\hline Total & 5.9 & & 82 & 93 & 42 & & $45.16 \%$ \\
\hline \multicolumn{8}{|l|}{ Céramique infiltrée de verre } \\
\hline Thoma DS. et al. (54) & 20179.6 & & 30 & 38 & 5 & & $13.16 \%$ \\
\hline Total & 9.6 & & 30 & 38 & 5 & & $13.16 \%$ \\
\hline \multicolumn{8}{|l|}{ Composite renforcé par fibre } \\
\hline Chen J. et al. (10) & 20172.7 & & 153 & 169 & 38 & & $22.49 \%$ \\
\hline Thoma DS. Et al. (54) & 20175 & & $>164$ & 267 & 20 & & $7.49 \%$ \\
\hline Total & 3.85 & & $>317$ & 436 & 58 & & $13.3 \%$ \\
\hline \multicolumn{7}{|c|}{ Reconstitution corono-radiculaire } & \\
\hline Cloet E. et al. (12) & 2017 & 5.8 & n.r & 100 & 24 & $24 \%$ & \\
\hline Sarkis-Onfore R. et al. (48) & 2014 & 3 & n.r & 37 & 1 & $2.7 \%$ & \\
\hline Total & & 4.4 & n.r & 137 & 25 & $18.25 \%$ & \\
\hline \multicolumn{8}{|c|}{ RCR foulée en technique directe } \\
\hline Bergoli CD.et al. (4) & 2017 & 3.1 & 129 & 152 & 9 & $5.92 \%$ & \\
\hline Cloet E. et al. (12) & 2017 & 5.8 & n.r & 65 & 13 & $20 \%$ & \\
\hline Sarkis-Onfore R. et al. (48) & 2014 & 3 & n.r & 41 & 3 & $7.32 \%$ & \\
\hline Total & & 3.97 & $>129$ & 258 & 25 & $9.69 \%$ & \\
\hline \multicolumn{8}{|c|}{ RCR foulée en technique indirecte } \\
\hline Cloet E. et al. (12) & 2017 & 5.8 & n.r & 26 & 5 & $19.23 \%$ & \\
\hline Total & & 5.8 & n.r & 26 & 5 & $19.23 \%$ & \\
\hline \multicolumn{8}{|l|}{ Technique de fabrication } \\
\hline \multicolumn{8}{|l|}{$\mathrm{CAD} / \mathrm{CAM}$} \\
\hline Rodrigues SB. et al. (42) & 2019 & 4.34 & n.r & 638 & 72 & $11.29 \%$ & \\
\hline Total & & 4.34 & n.r & 638 & 72 & $11.29 \%$ & \\
\hline \multicolumn{8}{|l|}{ Conventionnelle } \\
\hline \multirow{2}{*}{$\begin{array}{l}\text { Rodrigues SB. Et al. (42) } \\
\text { Total }\end{array}$} & 2019 & 4.34 & n.r & 585 & 34 & $5.81 \%$ & \\
\hline & & 4.34 & n.r & 585 & 34 & $5.81 \%$ & \\
\hline
\end{tabular}

Table 4: Study of the Different Types of Failure Depending on the Type of Prosthetic Restoration and the Material of Manufacture

\begin{tabular}{|c|c|c|c|c|c|c|c|c|c|c|c|c|}
\hline Study & $\begin{array}{l}\text { No. Res- } \\
\text { tauration }\end{array}$ & $\begin{array}{l}\text { Carie } \\
\text { secon- } \\
\text { daire }\end{array}$ & $\begin{array}{l}\text { Compli- } \\
\text { cation } \\
\text { endo- } \\
\text { dontique }\end{array}$ & $\begin{array}{l}\text { Compli- } \\
\text { cation } \\
\text { paro- } \\
\text { dontale }\end{array}$ & $\begin{array}{l}\text { Frature } \\
\text { tooth }\end{array}$ & $\begin{array}{l}\text { Frac- } \\
\text { ture de } \\
\text { la res- } \\
\text { taura- } \\
\text { tion }\end{array}$ & $\begin{array}{l}\text { Fracture } \\
\text { du maté- } \\
\text { riau de } \\
\text { revête- } \\
\text { ment : } \\
\text { Céra- } \\
\text { mique ou } \\
\text { compo- } \\
\text { site }\end{array}$ & $\begin{array}{l}\text { Descel- } \\
\text { lement/ } \\
\text { Décolle- } \\
\text { ment }\end{array}$ & $\begin{array}{l}\text { Pro- } \\
\text { blème } \\
\text { d'adap- } \\
\text { tation } \\
\text { margi- } \\
\text { nale }\end{array}$ & $\begin{array}{l}\text { Pro- } \\
\text { blème } \\
\text { esthé- } \\
\text { tique }\end{array}$ & $\begin{array}{l}\text { Autre } \\
\text { non } \\
\text { spé- } \\
\text { cifié }\end{array}$ & $\begin{array}{l}\text { No. } \\
\text { d'échec }\end{array}$ \\
\hline
\end{tabular}

Résine composite indi-

recte

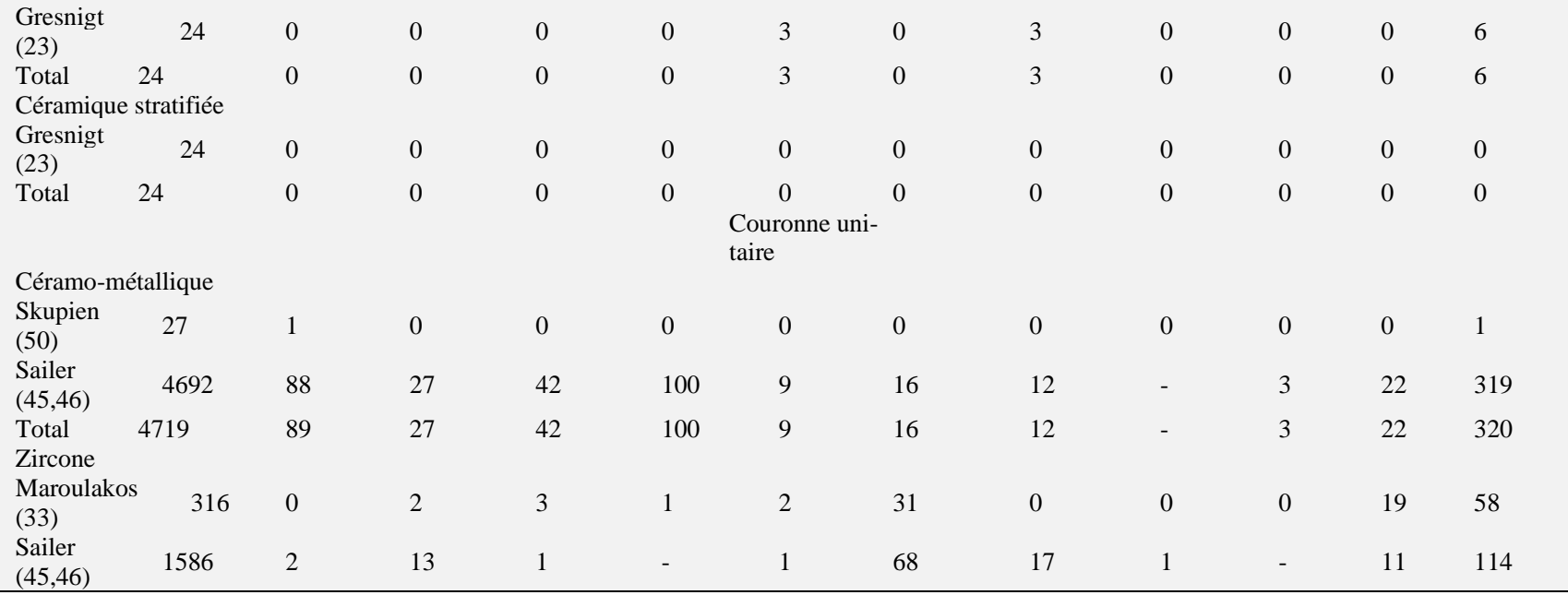




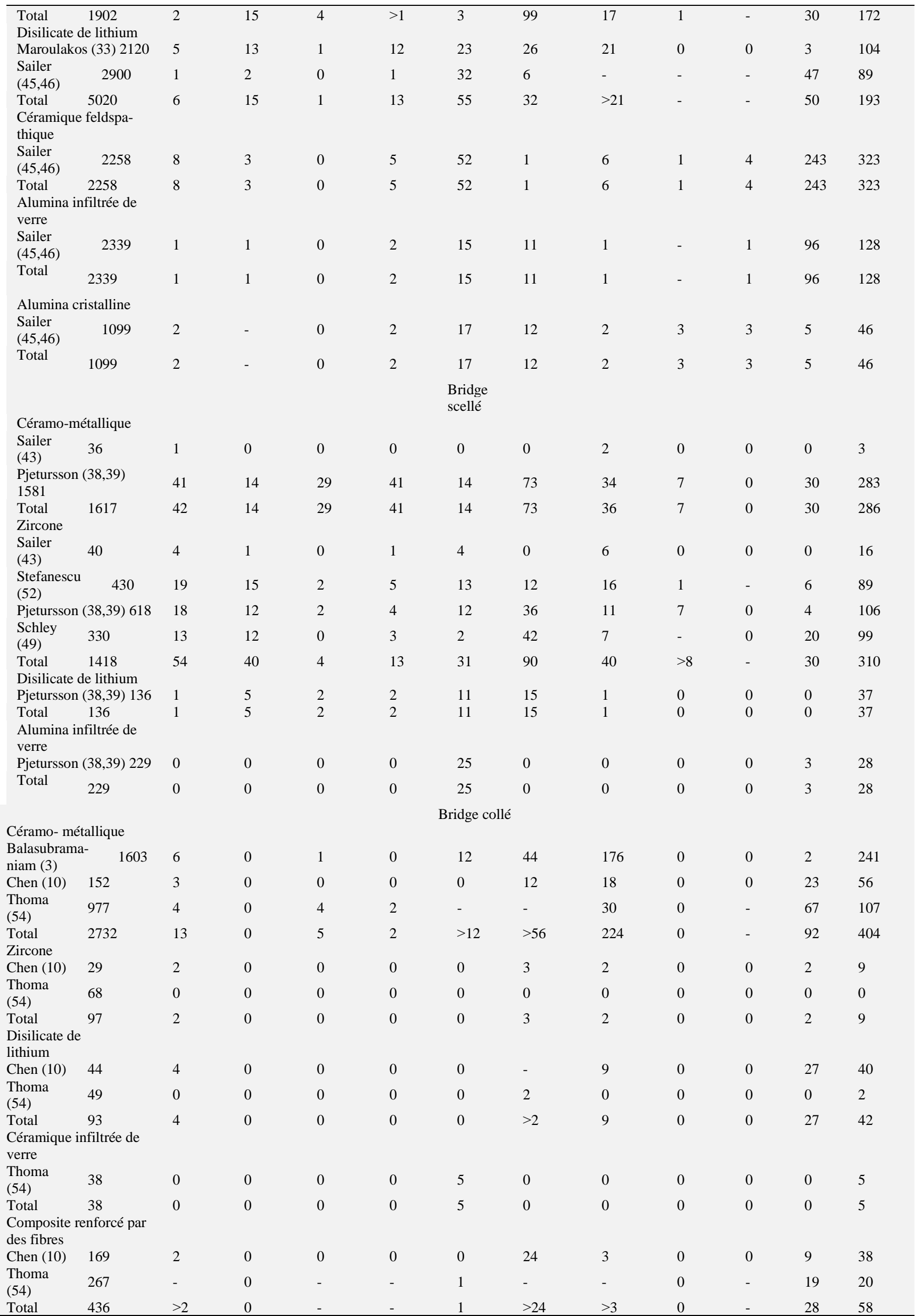




\begin{tabular}{|c|c|c|c|c|c|c|c|c|c|c|c|c|}
\hline \multicolumn{13}{|c|}{ Corono Radicular Reconstruction } \\
\hline \multicolumn{13}{|c|}{ CRR coulée indirecte technic } \\
\hline Cloet (12) & 100 & - & - & - & - & - & 0 & - & 0 & 0 & 24 & 24 \\
\hline Sarkis-Onfore (48) & 37 & 0 & 0 & 0 & 1 & 0 & 0 & 0 & 0 & 0 & 0 & 1 \\
\hline Total & 137 & - & - & - & $>1$ & - & 0 & - & 0 & 0 & 24 & 25 \\
\hline \multicolumn{13}{|c|}{ RCR foulée en technique directe } \\
\hline Bergoli (4) & 152 & 0 & 0 & 0 & 3 & 2 & 0 & 4 & 0 & 0 & 0 & 9 \\
\hline Cloet (12) & 65 & - & - & - & - & - & 0 & - & 0 & 0 & 13 & 13 \\
\hline Sarkis-Onfore (48) & 41 & 0 & 0 & 0 & 1 & 0 & 0 & 2 & 0 & 0 & 0 & 3 \\
\hline Total & 258 & - & - & - & $>4$ & $>2$ & 0 & $>6$ & 0 & 0 & 13 & 25 \\
\hline \multicolumn{13}{|c|}{ CRR foulée indirecte technic } \\
\hline Cloet (12) & 26 & - & - & - & - & - & 0 & - & 0 & 0 & 5 & 5 \\
\hline \multirow[t]{2}{*}{ Total } & 26 & - & - & - & - & - & 0 & - & 0 & 0 & 5 & 5 \\
\hline & & & & & \multicolumn{8}{|c|}{ Manufacturing technique } \\
\hline \multicolumn{13}{|l|}{ CAD/CAM } \\
\hline Rodrigues (42) & 638 & 2 & 3 & 0 & 0 & 22 & 0 & 30 & 0 & 2 & 13 & 72 \\
\hline Total & 638 & 2 & 3 & 0 & 0 & 22 & 0 & 30 & 0 & 2 & 13 & 72 \\
\hline \multicolumn{13}{|l|}{ Conventionnelle } \\
\hline Rodrigues (42) & 585 & 2 & 5 & 0 & 0 & 12 & 0 & 9 & 0 & 2 & 4 & 34 \\
\hline Total & 585 & 2 & 5 & 0 & 0 & 12 & 0 & 9 & 0 & 2 & 4 & 34 \\
\hline
\end{tabular}

- : Noreported.

CRR: Corono-radicular Reconstruction

Table 5: Description of Minor Complications:

\begin{tabular}{|c|c|c|c|c|c|c|c|}
\hline Study & Type of restauration & $\begin{array}{l}\text { Nomber of } \\
\text { restauration }\end{array}$ & $\begin{array}{l}\text { post opératoire sensi- } \\
\text { bility }\end{array}$ & $\begin{array}{l}\text { Retention of } \\
\text { plaque }\end{array}$ & Etat de surface & $\begin{array}{l}\text { Coloration de } \\
\text { surface }\end{array}$ & $\begin{array}{l}\text { Frittage } \\
\text { mineur }\end{array}$ \\
\hline $\begin{array}{l}\text { Gresgnit } \\
\text { MMM. et al. } \\
(23)\end{array}$ & Facette & 48 & $\begin{array}{l}\text { De } 8 \text { dents qui dispar- } \\
\text { ait après } 2 \text { semaines, } \\
\text { sans précision de type } \\
\text { de matériau. }\end{array}$ & $\begin{array}{l}\text { Des facettes } \\
\text { en résine } \\
\text { composite } \\
\text { indirecte. }\end{array}$ & $\begin{array}{l}\text { Rugosité de la sur- } \\
\text { face et perte de bril- } \\
\text { lance masquée par } \\
\text { la salive des facettes } \\
\text { en résine composite } \\
\text { indirecte. }\end{array}$ & - & - \\
\hline $\begin{array}{l}\text { Maroulakos } \\
\text { G. et al. (33) }\end{array}$ & Couronne & 2436 & $\begin{array}{l}\text { D'une dent avec } \\
\text { couronne en zircone } \\
\text { et de } 3 \text { dents avec } \\
\text { couronnes en disili- } \\
\text { cate de lithium. }\end{array}$ & - & - & - & - \\
\hline $\begin{array}{l}\text { Sailer I. et } \\
\text { al. }(45,46)\end{array}$ & Couronne & 14874 & - & - & - & $\begin{array}{l}\text { Coloration } \\
\text { marginale. }\end{array}$ & - \\
\hline $\begin{array}{l}\text { Stefanescu } \\
\text { C. et al. (52) }\end{array}$ & Bridge scellé & 430 & - & - & - & $\begin{array}{l}\text { Coloration de } \\
\text { surface. }\end{array}$ & $\begin{array}{l}\text { De } 61 \\
\text { bridges } \\
\text { scellés en } \\
\text { zircone. }\end{array}$ \\
\hline $\begin{array}{l}\text { Sailer I. et } \\
\text { al. (43) }\end{array}$ & Bridge scellé & 76 & - & - & - & - & $\begin{array}{l}\text { Frittage } \\
\text { mineur. }\end{array}$ \\
\hline $\begin{array}{l}\text { Pjetursson } \\
\text { BE. et al. } \\
(38,39)\end{array}$ & Bridge scellé & 2564 & - & - & - & $\begin{array}{l}\text { Coloration } \\
\text { marginale. }\end{array}$ & - \\
\hline $\begin{array}{l}\text { Schley JS. et } \\
\text { al. (49) }\end{array}$ & Bridge scellé & 330 & - & Présente & - & - & - \\
\hline $\begin{array}{l}\text { Chen J et al. } \\
\text { (10) }\end{array}$ & Bridge collé & 394 & $\begin{array}{l}\text { De } 16 \text { dents de tempé- } \\
\text { rature ou de pression } \\
\text { diminuant graduel- } \\
\text { lement après } 1 \\
\text { semaine à } 7 \text { mois. }\end{array}$ & - & - & $\begin{array}{l}\text { De } 21 \text { bridges } \\
\text { collés en com- } \\
\text { posite renforcé } \\
\text { par des fibres. }\end{array}$ & - \\
\hline $\begin{array}{l}\text { Rodrigues } \\
\text { SB. et al. } \\
\text { (42) }\end{array}$ & $\begin{array}{l}\text { Restauration fixée } \\
\text { par technique con- } \\
\text { ventionnelle ou } \\
\text { CAD/CAM }\end{array}$ & 1223 & - & - & $\begin{array}{l}\text { Problème au niveau } \\
\text { de l'état de surface. }\end{array}$ & $\begin{array}{l}\text { Coloration de } \\
\text { surface. }\end{array}$ & - \\
\hline
\end{tabular}

Biological chess was addressed by the study of Sailer I. et al. (43) on cement-retained bridges reported 5 cases of secondary caries including 3 sealed zirconia bridges and 1 metal-ceramic due to a failure at the level of the marginal adaptation detected at the time of implantation, 1 case of Longitudinal fracture of the abutment tooth of the sealed zirconia bridge took place 5.45 years after placement according to the study by Sailer I. et al. (43) and 2 cases of root fracture including a coronal-radicular reconstitution sprained by direct technique and a casting took place after 15 and 20 months consecutively according to Sarkis-Onfore R. et al.(48).

- Technical failures like the Restoration Fracture approached by Gresnigt MMM. et al. (23) all composite veneer fractures occurred at the incisal edge, and occurred consecutively at 11 months, 13 months and 6 years after placement, for Schley JS. et al. (49) 2 cases of restorative fracture including one at the connection of a 5-unit bridge and the other extending from the vestibular region to the palatal region of a 3-unit bridge.

According to Bergoli CD. et al. (4) 2 cases of fracture of the coronal radicular reconstitution sprained by direct technique, one occurred at the level of the post and the other at the level of the abutment of the teeth with a number of 0 to 1 residual coronary wall.

Loosening / Detachment: For Gresnigt MMM. et al. (23) the detachment was due to a failure of adhesion between the tooth and the glue and occurred 11 to 25 months after the placement of the indirect composite resin veneers, among 6 cases of loosening of the sealed zirconia bridges, 5 were due to a failure of adhesion between the dentin and the sealing cement remaining attached to the surface of the restoration 
according to Sailer I. et al. (43), and the study by Sarkis-Onfore R. et al. (48) reported 2 cases of detachment of fiberglass posts after 8 and 26 months.

- $\quad$ Failure and manufacturing technique:

Several included studies used either conventional or CAD / CAM techniques for the design of prostheses, but they did not investigate failure by technique, other than a single study by Rodrigues SB. et al. (42).

- $\quad$ Single crowns:

Among 367 crowns manufactured by the CAD / CAM technique, 49 cases of failure were reported, the most common failure was of a technical type: Loosening with 30 cases, and the other cases of failure were distributed as follows: 1 complication endodontic, 6 restorative fractures and 12 unspecified cases.

Among 379 crowns manufactured by the conventional technique, 24 cases of failure were reported, the most common failure was of a technical type: Loosening with 9 cases, and the other cases of failure were distributed as follows: 1 secondary caries, 4 endodontic complications, 6 restorative fractures and 4 unspecified cases.

Bridges:

Among 271 bridges made by the CAD / CAM technique, 23 cases of failure were reported, the most common failure was of a technical type: fracture of the restoration with 16 cases, and the other cases of failure were distributed as follows : 2 secondary caries, 2 endodontic complications and 3 unspecified cases.

Among 206 bridges manufactured by the conventional technique, 10 cases of failure were reported which were distributed as follows: 1 secondary caries, 1 endodontic complication, 6 restorative fractures and 2 unspecified cases.

Association between failure and localization:

4 studies investigated the association between failure and localization.

Bonded bridges:

- The review of Balasubramaniam GR. (3) reported 56 cases of detachment on 372 bridges at the anterior level and 49 cases out of 225 at the posterior level, 62 cases of detachment on 345 bridges at the maxillary level and 54 cases out of 219 at the mandibular level.Reconstitutions corono-radiculaires :

- The study by Cloet E. et al. (12) reported for coronal-radicular reconstructions cast in the indirect technique, 12 cases of failure in 40 anterior restorations and 12 cases in 60 posterior restorations, for coronal-radicular reconstructions sprained in the direct technique, 4 cases of failure in 16 anterior restorations and 9 cases out of 49 posterior restorations and for coronal-radicular reconstructions sprained in the indirect technique, 5 cases of failure in 12 anterior restorations and no cases in the 14 posterior restorations.

- The study by Sarkis-Onfore R. et al. (48) a for direct-technique sprained coronal-radicular reconstructions, 1 case of maxillary detachment in 23 anterior restorations, 1 case of detachment and 1 case of root fracture in two premolars in 18 posterior restorations, and for Coronoradicular reconstructions cast using the indirect technique, no failure in the 20 anterior restorations and 1 case of root fracture in one molar in 17 posterior restorations.

- The Bergoli CD Study. et al. (4) concluded among 152 coronal and radicular reconstructions sprained by direct technique, 6 cases of failure occurred in the premolars and 3 cases in the anterior: 2 lateral, 1 central.

Association between failure and type of cement / bonding material:

4 studies investigated the association between failure and type of cement / glue.

\subsubsection{Single crowns:}

a) The study by Maroulakos G. et al. (33):

- Zirconia: For 210 crowns sealed with adhesive resin, 36 cases of failure were reported. The most common failure was of a technical type: fracture of the cosmetic ceramic with 27 cases, the other cases of failure were distributed as follows: 1 dental fractures, 2 endodontic complications, 3 periodontal complications and 2 restoration fractures with no incidence of loosening and one unspecified case, for 106 crowns sealed with conventional cement, 22 cases of failure were reported. The most common failure was of a technical type: fracture of cosmetic ceramics. No incidence of restoration fracture or loosening was reported.

- Lithium disilicate: For 1957 cemented adhesive resin crowns, 95 cases of failure were reported. The most common failures were of the technical type with 25 cases of ceramic fracture, 21 cases of loosening and 20 cases of restoration fracture, the other cases of failure were distributed as follows: 12 dental fractures, 12 endodontic complications, 4 secondary caries and 1 periodontal complication, for 163 crowns sealed with conventional cement, 6 cases of failure were reported. The most common failure was of a technical type: fracture of the restoration with 3 cases, the other reported failures were: secondary caries, endodontic complication and fracture of the cosmetic ceramic.

With 3 unspecified cases of failure.

Cemented bridges:

- The review of Schley JS. et al. (49) reported for 156 bridges cemented with conventional cement, 5 cases of loosening occurred after $1,17,17,32$ and 38 months, and for 101 bridges cemented with adhesive resin, 2 cases of loosening occurred after 12 and 33 months.

\subsubsection{Coronoradicular reconstructions:}

- The study by Sarkis-Onfore R. et al. (48) reported for 37 cast coronal-radicular reconstructions bonded with a self-adhesive resin (3M TM RelyX TM U100), 1 case of root fracture was reported, for 21 coronal-radicular reconstructions sprained by direct technique bonded with a resin self-adhesive (3M TM RelyX TM U100), 1 case of root fracture was reported and for 20 coronal-radicular reconstructions sprained by direct technique bonded with a conventional resin (3M TM RelyX ${ }^{\text {TM }}$ ARC $+3 M^{\text {TM }}$ Single bond), 2 cases detachment were postponed.

- The Bergoli CD Study. et al. (4) reported for 76 coronal-radicular reconstructions sprained by direct technique bonded with a selfadhesive resin (3M TM RelyX TM U100 / U200), 1 case of root fracture, 1 case of detachment and 1 case of post fracture. been postponed and for 76 coronal-radicular reconstructions sprained by direct technique bonded with a conventional resin ( $3 \mathrm{M}^{\mathrm{TM}} \mathrm{RelyX}$ TM ARC $+3 \mathrm{M}$ TM Single bond), 2 cases of root fracture, 3 cases of detachment and 1 case of fracture of the abutment have been postponed

\subsection{Minor complications}


In this review, mild complications such as minor ceramic sintering, dentinal hypersensitivity that disappears or marginal stains were not considered to be a failure.

The studies that reported minor complications are detailed in Table V.

\subsection{Reintervention}

7 studies have mentioned the forms of reoperation.

\subsubsection{Secondary caries:}

Of the 330 zirconia bridges, 13 cases of secondary caries were detected among which 6 secondary caries were treated with composite, however 7 other caries caused the removal of the bridge (49).

Of the 394 bonded bridges, 11 cases of secondary caries were detected and conservative treatments were performed with the bonded bridges in place and in function (10).

\subsubsection{Endodontic complication:}

A periapical infection in a tooth with a lithium disilicate crown caused the tooth to be extracted (33).

- Among 330 zirconia bridges, 12 cases of endodontic complications were detected; 11 complications arose from loss of pulp vitality to which endodontic treatments were performed and one tooth with CPR presented with apical inflammation to which apical resection was performed (49).

- Carrying out of 2 endodontic treatments, one following severe postoperative sensitivity and one without specifying the cause (10).

\subsubsection{Tooth fracture:}

- $\quad$ The 2 fractured teeth (one among 37 cast CPR and one among 41 sprained CPR by direct technique) were extracted (48).

\subsubsection{Fracture of the restoration:}

- A Fracture was replaced by a new prosthetic restoration (12).

- Among 330 zirconia bridges, 42 cases of major ceramic sintering were detected and which were treated either by simple polishing or by repairing the sintered surface of the bridges cemented with direct composite (49).

\subsubsection{Loosening / Detachment:}

- The 3 detached indirect composite resin veneers out of 24 were re-glued after cleaning the surface of the veneer (23).

- 2 loosened zirconia bridges were recemented with the same type of cement after surface treatment (43).

- The loosened zirconia bridges were either recemented or replaced (49).

- $\quad$ The 2 detached fiberglass tenons out of 41 have been replaced by the same type of tenon (48).

\section{Discussion}

Our systematic review aimed to study prosthetic failures that could be encountered in fixed denture prosthesis and reoperation solutions, while summarizing the results obtained.

In this chapter, the first part will be dedicated to the methodology of the work, where the choice of inclusion criteria and the limits of our review will be discussed.

The second part will be devoted to the discussion of the results presented in the previous chapter where we will compare the results of our review with each other and with other publications.

The first step is to discuss the methodology and justify the choice of inclusion criteria:

In order to carry out a systematic review with a very high level of evidence, we retained that the randomized controlled trials, systematic reviews and meta-analyzes which are placed at the top of the Evidence Based Medicine pyramid (Appendix 5) (35).

In order to collect a sufficient number of articles for analysis, our review spanned a period of 10 years.

The methodical electronic search was carried out using 3 search engines, the aim was to encompass as many publications as possible. PubMed and Cochrane were the most convenient and efficient and accessible engines, on the other hand Science Direct was less practical and gave a lot of results with less specificity.

1) Qualitative evaluation of studies:

- Methodological quality:

We used the reading grids proposed by R. SALMI (47) in order to be able to criticize the methodological quality of the studies.

Regarding the systematic reviews, these grids allowed us to conclude that the majority of studies pursued a high quality methodology. With the exception of two systematic reviews $(38,45)$ which showed average quality.

2) Risks of bias:

The study of the bias of randomized controlled trials following the Cochrane Handbook (57) showed that:

- 2 studies had minimal risk of bias $(23,50)$

- 3 studies had an unclear risk of bias $(4,12,48)$.

- 1 study had a high risk of bias (43).

3) The limits of our study:

- Despite the choice of a 10-year filter and the use of different keywords in the different databases, we did not find enough studies dealing with the reintervention component.

- We did not take the abandonment into consideration because it is not detailed in the studies selected for each type of restoration or material. 
- 2 systematic reviews with their answers $(38,39,45,46)$ presented contradictions which revealed errors during the extraction of data from the articles selected in their studies, so we had recourse to their bibliographic references.

- The included studies only treated patients without general, occluso-functional, periodontal problems.

- Great heterogeneity: We were faced with the difficulty of synthesizing all the research findings, due in particular to the difference in the protocols recommended, the variety of types and materials for restoration and the gluing or sealing products suggested.

In this second part of the discussion, the results found in the articles included in our systematic review are discussed among themselves and through other publications.

Chess were classified according to the type of restoration:

Facets:

Several clinical trials have been performed to compare ceramic veneers with indirect composite resin veneers in vivo, however none had a follow-up for more than 10 years (in 23).

The study by Gresnigt MMM. et al. (23) was the first to have compared them in vivo with a 10-year follow-up. Ceramic veneers at the anterior maxillary level in this study showed significantly better performance with a zero failure rate compared to those with indirect composite resin which showed a $25 \%$ failure rate after 10 years of service. In contrast, in a randomized clinical trial with 3 years of followup similar failure rates were obtained between the two types of material (24).

All indirect composite veneer fractures occurred at the incisal edge, this could be related to chewing movements and contact with opposing teeth at the joint (23).

Qualitatively, the most frequently observed differences were the roughness of the surface which promoted plaque retention as well as the loss of saliva-masked shine of the indirect composite resin veneers (23). This has been shown by a study where minor complications were also observed but not considered significant between the two materials, with the exception of surface roughness (24). Indeed, the surface degradation affected not only the aesthetic appearance but also the plaque build-up (23).

Yet indirect composite resin restorations are easy to bond and repair, have higher flexural modulus, lower cost, and less abrasive to opposing teeth (32).

Single crowns:

All-ceramic type single crowns exhibited a significantly similar failure rate compared to the metal-ceramic "gold standard", with the highest failure rates found in feldspathic ceramic (14.3\%) as well as zirconia (9.04\%).

- Association between failure and sealing cement:

The qualitative assessment by Maroulakos G. et al. (33) showed comparable survival and failure rates between adhesive resin cemented crowns and conventional cement crowns. The most common failure for adhesive resin-sealed zirconia crowns and conventional cement was fracture of the veneering ceramic which may not be related to the type of cement (33). However, this failure could depend on the thickness of the veneering ceramic, the design of the zirconia framework and its thickness (51). This was not the case for lithium disilicate crowns cemented with adhesive resin where the most common failures were loosening as well as fracture of the restoration, and for those cemented with conventional cement where failure the most. current was the restoration fracture.

- Technical failures:

Technically, ceramic fracture and restoration were the most common failures in all-ceramic crowns. This was specifically encountered when weak ceramic materials were used (in 45). However, for ceramic metal crowns, ceramic fracture was the most common failure.

- Biological failures:

Biologically, the all-ceramic crowns showed better performance than the "gold standard" which had higher incidences of dental fracture, secondary decay and periodontal complication. These biological complications could influence the prognosis of abutment teeth or even cause their loss as well as that of the restorations.

In comparison, these complications are rarely reported for all-ceramic crowns, which could direct practitioners to these types of material (45).

Therefore, it was shown that all-ceramic lithium disilicate or alumina crowns could be recommended as an alternative therapeutic option to ceramic metal at the anterior and posterior level (in 45). However, feldspathic ceramic could only be recommended at the anterior level with less occlusal forces (45).

Zirconia crowns showed poor clinical performance despite their mechanical stability. The ceramic fracture was the most common failure for this type of ceramic when compared to other types of all-ceramic or even ceramic-metal material.

Despite progress and efforts to improve zirconia plating procedures, the sintering problem could not be resolved (31), so zirconia crowns could not be the first therapeutic treatment of choice. (45).

Cemented bridges:

Metal-ceramic cement-retained bridges had a low failure rate (17.69\%) compared to all-ceramic ones; zirconia and lithium disilicate which showed failure rates of $21.86 \%$ and $27.21 \%$ respectively but higher compared to alumina bridges $(12.23 \%)$.

- Technical failures:

Technically, ceramic fracture was the most common failure in all-ceramic bridges as well as metal-ceramic.

For zirconia bridges, 2 studies $(38,49)$ had ceramic fracture as the most common failure, while loosening was the most common in the other 2 studies $(43,52)$. As was also the case in the literature where ceramic fracture was the main failure of bridges, a prospective study on zirconia bridges (41) showed a ceramic fracture rate of $25 \%$, creating general doubt. on the design of zirconia bridges.

The fracture of the ceramic was a problem encountered at the level of ceramic-metal bridges (in 43), as well as those in zirconia (in 43). However, the extension of the fracture was wider in the latter (43). In addition, a systematic review on metal-ceramic and zirconia bridges (25) showed a higher ceramic fracture rate for zirconia (54\% Zirconia / 34\% metal-ceramic). This could be explained by the residual stress occurring during manufacturing procedures and also the cracks induced by occlusal contacts according to the study by Swain MV. (53). According to the study by Pjetursson BE. et al. (38) the fracture of the restorations was also one of the major failures for lithium disilicate and alumina bridges, especially in the posterior region which could be due to a diameter of the connections below 4 mm $\times 4$ mm (in 38 ). It has also been shown that all-ceramic bridges more often endure parafunction and malocclusion problems, thus causing their fractures (in $38)$.

- Association between failure and sealing cement:

The restoration fracture was a more common failure in zirconia than in metal-ceramic, but loosening on the other hand was a considerable failure for the latter. The systematic review, which studied the survival of zirconia bridges (49), reported cases of loosening for both conventional cement and adhesive resin cemented bridges with the same preparation techniques. Therefore, the retention was not decisively influenced by the shape of the abutment, nor the type of cement. 
- Minor complications:

Regarding minor sintering, it was found in the study by Stefanescu C. et al. (52) which treated zirconia bridges with 61 cases (14.19\%), but also in the study by Sailer I. et al. (43) with a significantly similar rate for $38 \%$ zirconia bridges and $33 \%$ metal-ceramic bridges, where it was correlated with occlusal wear of the ceramic in the 2 types of material, as shown by a fractographic analysis of the replicas. sintered bridges (36).

- Biological failures:

Biologically, all-ceramic bridges as well as metal-ceramic bridges were similar in performance. The main failures found in ceramic-metal bridges were: secondary caries and dental fractures, however in all-ceramic ones; endodontic complications and secondary caries were the most common. This was confirmed by the 4 studies which treated zirconia bridges $(38,43,49,52)$, but for those in lithium disilicate it was more endodontic complications, on the other hand those in alumina did not present any failure. biological order.

On the one hand, this could be explained by the problem of marginal adaptation especially encountered with all-ceramic bridges manufactured by the CAD / CAM technique (in 38).

Despite the problems found with zirconia bridges, whether biological or technical, compared to other types of all-ceramic and metalceramic material, zirconia has shown satisfactory performance, especially if it is not used for restorations of long span, respecting the criteria of the diameter of the connections (38), this is valid for other all-ceramic bridges.

Bonded bridges:

Metal-ceramic bonded bridges had an almost similar failure rate (14.79\%) to that of glass-infiltrated ceramic (13.16\%) and fiber-reinforced composite $(13.3 \%)$ bridges, on the other hand it was significantly higher. lower than that of lithium disilicate bridges (45.16\%) and higher than those of zirconia $(9.28 \%)$.

2 studies concerning ceramic-metal bridges (3.54) showed approximately similar failure rates while the study by Chen J. et al. (10) had a higher failure rate of $36.84 \%$.

For all-ceramic bridges the highest failure rate was found for lithium disilicate bridges. This is explained by the study conducted by Chen J. et al. (10) which showed that the mechanical properties of lithium disilicate might not be able to resist masticatory forces at the posterior level.

- Technical failures:

Technically, detachment was the most common failure in all-ceramic bridges as well as metal-ceramic, with a higher number of cases in the latter. But also the ceramic fracture was a relatively important failure for metal-ceramic bridges. As is Pjetursson BE. et al. (40) who reported detachment as the main failure in their study, with $19.2 \%$ of bridges affected within 5 years.

It has been reported that the interface between the metal and the veneering ceramic is the weak point of metal-ceramic bridges. In addition, the visibility of the metal of the fins or by transparency through the ceramic could constitute an aesthetic limitation of this type of material (10).

Zirconia bridges showed the lowest failure rate compared to other all-ceramic materials with 9 cases of failure reported by the study by Chen J. et al. (10), which split between ceramic fracture and detachment, faced with no failure for the Thoma DS study. et al. (54).

While for those made of fiber-reinforced composites, the fracture of the coating composite was the main failure. Fiber-reinforced composite bridges had a modulus of elasticity close to that of dentin (in 10), while all-ceramic materials exhibited less rigidity and therefore prone to fracture (in 10). Therefore, no case of fiber reinforced composite bridge fracture was detected.

- Association between failure and localization:

Balasubramaniam GR. (3) in his review reported that metal-ceramic bridges located at the maxillary level had a higher survival rate than those at the mandibular level, which confirmed the results of the review by Pjetursson BE. el al. (40) who studied the survival of bonded bridges over a period of 5 years. As with the anterior metal-ceramic bridges which had a higher survival rate than the posterior ones, also similar results were found in the previous review (40) which showed a high annual detachment rate at the posterior level (5.03\%) compared to the anterior region (3.05\%). However, according to the review of Cruegers NH. et al. (14), some studies affirmed that posterior bridges were more retentive than anterior ones. This could be due to a difference in the form of the preparation between the two regions (3).

- Association between failure and type of preparation:

Several studies favored bridges without preparation or with a preparation limited to enamel, since adhesion to dentin is weaker than to enamel, which could influence retention (in 3).

For anterior level bridges, less invasive preparations are considered sufficient for most authors. On the other hand, in order to improve retention at the posterior level, the extension of preparations to this region was recommended, which did not rhyme with conservative methods (in 54). Increasing the bonding area has been recommended by several studies, fins with $180^{\circ}$ extension around the axial abutment surface are found to improve retention (in 3), which followed the Wyatt CC study . (56) which showed that modifying the preparation form increased the retention and strength of bonded bridges. While the study by Cotert S. and Ozturk B. (13) reported that the type of the fins and the design of the proximal preparation had no significant effect on the survival of bonded bridges.

- Association between failure and bonding material:

As for sizing, Panavia TM glue showed a higher survival rate than other sizing agents (3). Which was approved by the Durey KA study. et al. (16) which revealed early degradation of the bonding composite as well as a decrease in bond strength unlike Panavia TM adhesive. According to Ibbeston R. (27) compromises could arise in the case where the bonding of the bridges was made in the absence of a dam.

- Biological failures:

Biologically, all-ceramic and fiber-reinforced composite bridges performed better than metal-ceramic bridges that had higher incidences of secondary caries. In fact, several researchers reported that bonded bridges had a high risk of secondary decay (in 10). The incidence of laboratory failures was significantly lower than technical failures.

As partial detachment caused a high risk of secondary decay, the high bonding ability between the resin and the fiber reinforced composite (in 10) could be the reason for the low incidence found in this type of material.

In addition, exposure of dentin increased the risk of hypersensitivity and decay if it was not properly sealed during bonding, thereby increasing the risk of failure (3).

According to Balasubramaniam GR. (3) several studies recommended supragingival limits which allowed adequate maintenance of hygiene and therefore prevent gum and periodontal diseases as well as caries. Moreover, the endodontic and periodontal health of the abutment teeth played an important role in the indication of bonded bridges.

Admittedly, fiber-reinforced composite bridges had acceptable functional and aesthetic performance as well as lower cost than all-ceramic ones. But their indications remain limited during the term (10). 
However, bonded bridges could not be indicated in all clinical situations. Severe malocclusions and enamel insufficiency presented limitations or even contraindications for bridges glued (29).

Coronoradicular reconstructions:

The cast coronal-radicular reconstructions presented a failure rate (18.25\%) approximately similar to those sprained in the indirect technique $(19.23 \%)$, on the other hand higher than those sprained in the direct technique $(9.69 \%)$. This could be explained by the fact that the fiberglass posts had mechanical properties similar to those of dentin, so the risk of fracture was reduced (in 48).

A retrospective study (19) had similar results, of which failures were observed more at the level of teeth restored by metal posts. On the other hand, the results of 4 systematic reviews showed similar performance between metal posts and fiberglass posts $(7,20,21,26)$. It therefore appeared that the type of coronary root reconstruction did not influence the failure rate (12).

- Biological and technical failures:

All of the included studies that treated coronary radicular reconstructions did not report the specific number of each type of failure.

However, a retrospective study (17) not included in our review treating 985 glass fibers reported 79 cases of failure: 39 endodontic complications, 1 root fracture, 1 post fracture, 17 crown loosening, 21 post detachments, without take into account the number of residual walls, although the authors considered that mechanical failures were related to the latter factor.

As approved by the study by Ferrari M. et al. (18) who analyzed the influence of the number of residual walls of endodontically treated premolars over a 6-year period, showing that preserving at least one wall significantly reduced the risk of failure.

- Association between failure and type of cement / bonding materials:

The Study of Bergoli CD. et al. (4) studied the effect of two types of glue on glass fibers, their results showed that the failure of the fibers did not depend on the type of glue. However Sarkis-Onfore R. et al. (48) in their study used the same bonding strategy (self-adhesive) for both types of posts, fiberglass and metal, which exhibited easy handling as well as good wettability tolerance.

- Association between failure and localization:

Regarding the location, according to Bergoli CD. et al. (4), cases of failure are observed more in the anterior teeth and premolars compared to molars where no failure has been reported. This could be due to the fact that the anterior teeth and premolars received oblique occlusal forces harmful to the restorations compared to the vertical forces (in 4). In addition, the width of the occlusal surfaces of the molars allowed better dissipation of forces (4).

In addition, the maxillary region is considered a high risk region for technical failure due to the magnitude of horizontal forces (48). As a result, more failure occurred in the anteromaxillary region.

For Cloet E. et al. (12) the main failure was the loosening of the posts with a rate of $30.9 \%$ at the anterior level and $18.02 \%$ at the posterior level. As reported in a review of the literature (55) which stated that post failure in the incisors and canines occurred approximately three times more than in premolars and molars.

Apart from the type and position of the teeth at the level of the arch, the absence of proximal contacts as well as the type of coronary restoration (single or plural) were factors in the failure of coronal and radicular reconstructions (in 12 ). Therefore, two included studies $(4,48)$ have restored the teeth treated with ceramic-metal crowns, with the same technique and the same type of cement $(4)$, in order to be able to assess the failure in relation to the type of Coronoradicular reconstitution independently of the type of coronary restoration (48).

In fact, the patient could also influence the survival of restorations through their hygiene habits, occlusal characteristics, etc. (4). Moreover, the occlusal contacts of the coronary restorations with the opposing teeth had to be evaluated since any problem related to these factors could generate failures independently of the coronal-radicular reconstructions (48).

According to the results of the various studies, glass fibers could be indicated as an alternative to metal posts thanks to their mechanical and aesthetic properties (48).

Manufacturing techniques:

While in our review, some included studies used CAD / CAM techniques for the design of prostheses, but they did not study failure based on the techniques used, apart from the study by Rodrigues SB. et al. (42).

Fixed restorations fabricated by CAD / CAM techniques had a high failure rate (11.29\%) compared to those fabricated by conventional techniques $(5.81 \%)$.

- Biological and technical failures:

The most common failures for both types of fabrication technique were; loosening and fracture of the restoration or ceramic, with significantly higher values for CAD / CAM techniques. Likewise for the study by Beuer F. et al. (5) who reported higher cases of fracture for the $\mathrm{CAD} / \mathrm{CAM}$ technique as well as two studies included in the review $(38,45)$ which showed high cases of ceramic fracture.

Studies from one review included (49) in our review used CAD / CAM techniques for the design of restorations; the study by sailer I. et al. (44) explained the cases of failure found by the CAD / CAM technique used which could cause marginal adaptation problems. This was endorsed by a systematic review (37) which stated that the CAD / CAM technique exhibited poor results regarding the marginal fit of lithium disilicate restorations.

- Minor complications:

All the studies that reported marginal staining of zirconia restorations, explained the high rate of hiatus and marginal staining by the use of CAD / CAM techniques (in 38). This showed their lack of precision (43). In particular, a randomized controlled trial comparing fixed metal-ceramic and zirconia restorations (44) demonstrated larger internal gaps in zirconia made by the CAD / CAM technique compared to metal-ceramic in the conventional technique, which which could explain the high rate of marginal staining. In the literature, internal vacancy values for zirconia restorations (CAD / CAM) ranged from $140( \pm 26) \mu \mathrm{m}$ in in vitro studies (9) to $130( \pm 56) \mu \mathrm{m}$ in vivo (8). Recently, smaller values have been reported $88.27( \pm 41.49) \mu \mathrm{m}$ and $92.13( \pm 49.87) \mu \mathrm{m}(2)$.

On the other hand, conventional techniques could reduce the incidence of sintering of cosmetic ceramics due to the strong adhesion between veneer ceramic and framework (42).

- Association between failure and localization:

The incidence of sintering is influenced by the position of the teeth on the arch, crowns placed anteriorly had a longer survival time than those placed posterior, as a result of the difference in the directions of the occlusal forces (28).

However for Rodrigues SB. et al. (42), the performance of crowns placed anterior and posterior was compared and no significant difference was observed for those in metal-ceramic, lithium disilicate, alumina and zirconia. While those in feldspathic ceramic showed a lower survival rate posterior than anterior $(87.8 \%$ versus $94.6 \%)$.

Recently, the CAD / CAM technique has seen many advances, and thanks to the introduction of clinical recommendations for the preparation of abutment teeth, the clinical performance of restorations using the CAD / CAM technique could see improvements (43). 
The studies included in our review which treated the reintervention component did not respond explicitly to our vision for this component. As well as the literature which was limited to materials and techniques of reoperation as well as the behavior to be taken in the face of the various forms of failure without mentioning the therapeutic solutions adopted to replace a non-conservable restoration.

It is important to make the diagnosis and eliminate the reason for the failure before proceeding with the reoperation, as otherwise the repaired restoration could be subject to recurrence of failure or even a more serious one.

There are two forms of reoperation:

Reoperation without removal:

Repair, when possible, offered an attractive alternative. In addition, it is considered the least mutilating and often the least expensive intervention. The repair was a treatment in its own right and made it possible to extend the life of the prosthesis (15).

Repair may be necessary for endodontic, periodontal or technical problems (15).

- $\quad$ Faced with endodontic failures:

In two studies $(10,49)$, pulp inflammation as well as loss of vitality were treated endodontically without detailing the protocol.

According to the literature (15) the treatment of irreversible pulp inflammation could be carried out either by a trepanation cavity through the crown or by retrograde approach (apical surgery) and this is indicated: when conventional endodontic treatment could not be carried out, face failure after endodontic retreatment in which the lesion did not heal and when resumption of endodontic treatment proved impossible in the following cases: a fractured instrument, an overly complex root morphology, a cast corono-radicular reconstruction or a prosthetic element in the removal could pose a risk of root fracture.

As was the case with the review conducted by Schley JS. et al. (49) where apical resection was performed following apical inflammation. This retrograde approach could be justified even if trepanation or disassembly of the prosthetic element did not present any particular risk, in order to avoid the removal of a perfectly integrated joint prosthesis, both periodontally and aesthetically and when the prognosis after endodontic surgery was very favorable (15).

- Faced with periodontal failures:

- Among the treatments we found: connective tissue grafting which had many indications such as: root coverage, filling of ridges, treatment of gingival dyschromia, creation of papillae, recovery of a post-prosthetic recession ... (15) .

- However, some recessions related to iatrogenic prosthetic design or related to aging of the periodontium could not be treated by keeping the prosthesis (15).

- $\quad$ Faced with technical failures:

- Clinical situations that fell within the scope of indication for repair are limited to cases of ceramic fracture or improper morphology requiring repair by simple grinding (15).

- In the case of ceramic fracture, the treatment depended on the nature of the exposed surface; for the metallic surface, the repair was done by the composite and for the ceramic surface, it was done by the ceramic (15).

- Intraoral repair, which was usually a temporary intervention, prevented the inconvenience of removing restorations while maintaining their function and preventing the build-up of microorganisms on the fractured surface. For minor sintering in the posterior region and only if the metal or ceramic framework was not exposed, a simple polishing of the surface may be sufficient (30). As was the case with Schley JS's journal. et al. (49) where the sintering of the ceramic has been treated either by simple polishing or by repairing the sintered surface of the bridges sealed with direct composite.

For a major sintering, three possibilities of reoperation existed:

- The replacement of the fractured cosmetic ceramic fragment by composite resin (30), which could have a reserved prognosis given that the composites were susceptible to wear and their color was not stable compared to ceramic (22).

- Re-bonding of the fragment fractured by resin (30),

- Preparation of the restoration to accommodate a new ceramic veneer (veneer and overlay) for aesthetic requirements or for long extended fractures. The latter alternative allowed the elimination of premature contact and thus corrected the occlusion which could be the cause of the failure (30).

Proper surface conditioning is essential for the success of intraoral repairs. So the practitioner had to choose the appropriate surface treatment according to the exposed material of the fractured surface (30); Several studies have shown that the application of silane significantly increases the bond strength between the repair composite and the ceramic. While the silica coating of the two substrates; ceramic and metal-ceramic, followed by the application of silane provided better adhesion compared to other techniques (6). Also reported by Balasubramaniam GR. (3) which claimed that the surface treatment of the fins with the silica coating provided better retention than other materials, so it is also recommended for re-bonding; however, these repair techniques are considered temporary because the bond strength decreased over time (22). This was the case in the review by Balasubramaniam GR. (3) concerning bonded bridges where re-bonding was the most frequent intervention in most cases of failure. However, re-bonded restorations were more likely to detach than those without a history of detachment. Thus the survival of the new bonded replacement bridges was significantly better than the bonded ones, which was explained by the decrease in the retention capacity of the fins and abutment teeth.

Reasons for using no-removal repair techniques, other than those listed above, included the desirability of avoiding more clinical sessions as well as performing the provisional, reducing cost and eliminating risks. iatrogenic associated with the realization of a new restoration (6).

Reoperation with removal:

When the repair of the prosthesis proves impossible, the practitioner will resort to reoperation with removal. Different materials and materials are used depending on the chosen removal technique and the prosthetic element (single or multiple). Depending on the case, the removal could be done with or without alteration of the prosthetic element.

The difficulty of removal depended on the type of restoration, the composition of the assembly materials and the nature of the prosthetic materials used.

This type of intervention could require the design of a temporary prosthesis that could be either fixed or attached; it allowed the modification of the occlusion ratios and is intended to restore or preserve aesthetics and function, it contributed to the maintenance of the periodontal environment and ensured the protection of the residual teeth. 


\section{Recommendations}

More studies should be carried out concerning: the reoperation component following the removal of a non-repairable prosthesis and the CAD / CAM techniques by studying the failure according to these techniques.

The effects of different types of cement or bonding material on the survival of different types of fixed tooth-supported restorations

\section{Conclusion}

In short, in fixed prosthesis, failures have particularly serious consequences and can occur at all levels involved for these restorations. They can happen at any time.

This is how we were able to note the influence of certain variables on the success and durability of the treatments, which did not depend only on the skill and precision used during prosthetic development, such as the location, arch, preparation design, number of abutments, type of material used, bonding material, surface treatment and technologies used.

So the choice of restorative materials was a decisive factor that had to be the result of a careful study of the different materials available depending on the clinical situation, in order to increase their longevity and therefore reduce the risk of failure.

Faced with failures, the practitioner had to make the decision to reopen with or without removal of the restoration, so the overall longevity of a prosthesis depended in part on the number of repairs it could accept.

Prevention remained the best way to avoid these failures. And perfect mastery of clinical and laboratory sequences ensured the success and durability of the joint prosthesis.

Despite the limitations of our review, we can conclude that:

- Ceramic veneers performed significantly better compared to indirect composite resin veneers at the anteromaxillary level.

- All-ceramic single crowns had an almost similar failure rate compared to metal-ceramic, so they could be an alternative to the "gold standard".

- Ceramic-metal cement-retained bridges showed a low failure rate compared to all-ceramic ones, so the latter could not be an alternative to metal-ceramic especially for long-span restorations.

- Zirconia may have been the material of choice for bonded bridges, however the indication for fiber-reinforced composite bridges was limited over time.

- Glass fibers could be indicated as an alternative to metal posts for the realization of coronal-radicular reconstructions.

- Fixed restorations fabricated using CAD / CAM techniques exhibited poor performance compared to those fabricated using conventional techniques.

- $\quad$ More studies are needed to develop the re-intervention component.

\section{References}

[1] AFRASHTEHFAR KI, EMAMI E, AHMADI M, ABI-NADER S, TAMIMI F. Failure rate of single-unit restorations on posterior vital teeth: A systematic review. J Prosthet Dent. 2017, 117(5):345-53, 353.e1-353.e8. https://doi.org/10.1016/j.prosdent.2016.08.003.

[2] AHRBERG D, LAUER HC, AHRBERG M, WEIGL P. Evaluation of fit and efficiency of CAD/CAM fabricated all-ceramic restorations based on direct and indirect digitalization: a double-blinded randomized clinical trial. Clin Oral Investig. 2016, vol 20(2), p.291-300. https://doi.org/10.1007/s00784-015-1504-6.

[3] BALASUBRAMANIAM GR. Predictability of resin bonded bridges - a systematic review. Br Dent J. 2017, vol 222(11), p. 849-858. https://doi.org/10.1038/sj.bdj.2017.497.

[4] BERGOLI CD, BRONDANI LP, WANDSCHER VF, PEREIRA GKR, CENCI MS, PEREIRA-CENCI T, VALANDRO LF. A multicenter randomized double-blind controlled clinical trial of fiber post cementation strategies. Oper Dent. 2018, 43-2, 128-135. https://doi.org/10.2341/16-278$\underline{\mathrm{C}}$.

[5] BEUER F, SCHWEIGER J, EICHBERGER M, KAPPERT HF, GERNET W, EDELHOFF D. High-strenght CAD/CAM-fabricated veneering material sintered to zirconia copings - a new fabrication mode for all-ceramic restorations. Dent Mater. 2009, vol 25, p. 121-128. https://doi.org/10.1016/i.dental.2008.04.019.

[6] BLUM IR, JAGGER DC, WILSON NHF. Defective dental restorations: to repair or not to repair? part 2: all-ceramics and porcelain fused to metal systems. Dental Update. 2011, vol 38(3), p. 150-158. https://doi.org/10.12968/denu.2011.38.3.150.

[7] BOLLA M, MULLER-BOLLA M, BORG C, LUPI-PEGURIER L, LAPLANCHE O, LEFORESTIER E. Root canal posts for the restoration of root filled teeth. Cochrane database of systematic reviews. 2013. CD004623

[8] BRAWEK PK, WOLFART S, ENDRES L, KRISTEN A, REICH S. The clinical accuracy of single crowns exclusively fabricated by digital workflow - the comparison of two systems.Clin Oral Investig. 2013, vol 17(9), p. 2119-2125. https://doi.org/10.1007/s00784-013-0923-5.

[9] BUCHI DL, EBLER S, HAMMERLE CH, SAILER I. Marginal and internal fit of curved anterior CAD/CAM-milled zirconia fixed dental prostheses: an in-vitro study. Quintessence Int. 2014, vol 45(10), p. 837-846.

[10] CHEN J, CAI H, SUO L, XUE Y, WANG J, WAN Q. A systematic review of the survival and complication rates of inlay-retained fixed dental prostheses. J Dent. 2017, vol 59. https://doi.org/10.1016/j.jdent.2017.02.006.

[11] CHO HY, WON HY, CHOE HC, SON MK. Fracture characteristics of dental ceramic crown according to zirconia coping design. Procedia Engineering. 2011, vol. 10, p. 1561-1566. https://doi.org/10.1016/j.proeng.2011.04.261.

[12] CLOET E, DEBELS E, NAERT I. Controlled clinical trial on the outcome of glass fiber composite cores versus wrought posts and cast cores for the restoration of endodontically treated teeth: a 5-year follow-up study. Int J Prosthodont. 2017, vol 30(1), p. 71-79. https://doi.org/10.11607/ijp.4861.

[13] COTERT S, OZTURK B. Posterior bridges retained by resin-bonded cast metal inlay retainers: a report of 60 cases followed for 6 years. J Oral Rehabil. 1997, vol 24, p. 697-704. https://doi.org/10.1046/j.1365-2842.1997.00548.x.

[14] CREUGERS NH, KAYSER AF, VAN'T HOF MA. A seven and a half year survival study of resin-bonded bridges. J Dent Res. 1992, vol 17(11), p. 1822-1825. https://doi.org/10.1177/00220345920710111101.

[15] DECUP FRANCK. Protocoles de réparation en dentisterie esthétiques. Réal Clin. 2000, vol 11(3), p. 263-275.

[16] DUREY KA, NIXON PJ, ROBINSON S, CHAN MF. Resin bonded bridges: techniques for success. Br Dent J. 2011, vol 211, p. 113-118. https://doi.org/10.1038/sj.bdj.2011.619.

[17] FERRARI M, CAGIDIACO MC, GORACCI C, ET AL. Long-term retrospective study of the clinical performance of fiber posts. Am J Dent. 2007, vol 22, p. 287-291.

[18] FERRARI M, VICHI A, FADDA GM, ET AL. A randomized controlled trial of endodontically treated and restored premolars. J Dent Res. 2012;91:72S-78S. https://doi.org/10.1177/0022034512447949. 
[19] FERRARI M, VICHI A, GARCIA-GODOY F. Clinical evaluation of fiber-reinforced epoxy resin posts and cast post and cores. Am J Dent. 2000, vol 13, p. 15B-18B.

[20] FEDOROWICZ Z, CARTER B, DE SOUZA RF, DE ANDRADE LIMA CHAVES C, NASSER M, SEQUEIRA-BYRON P. Single crowns versus conventional fillings for the restoration of root filled teeth. Cochrane database of systematic reviews. 2013; 5:CD009109. https://doi.org/10.1002/14651858.CD009109.pub2

[21] FIGUEIRIDO FE, MARTINS-FILHO PR, FARI ES. Do metal post-retained restorations result in more root fractures than fiber post-retained restorations? a systematic review and meta-analysis. J Endod. 2015, vol 41, p. 309-316. https://doi.org/10.1016/j.joen.2014.10.006.

[22] GALIATSATOS AA. An indirect repair technique for fractured metal-ceramic restorations: A clinical report. J Prosthet Dent. 2005, vol 93(4), p. 321-323. https://doi.org/10.1016/j.prosdent.2004.12.018.

[23] GRESNIGT MMM, CUNE MS, JANSEN K, VAN DER MADE SAM, OZCAN M. Randomized clinical trial on indirect resin composite and ceramic laminate veneers: Up to 10-year findings. J Dent. 2019, vol. 86, p. 102-109. https://doi.org/10.1016/j.jdent.2019.06.001.

[24] GRESNIGT MMM, KALK W, OZCAN M. Randomized clinical trial of indirect resin composite and ceramic veneers: up to 3-year follow up. J Adhes Dent. 2013, vol 15, p. 181-190.

[25] HEINTZE SD, ROUSSON V. Survival of zirconia- and metal-supported fixed dental prostheses: a systematic review. Int J Prosthodont. 2010, vol 23(6), p. 493-502

[26] HEYDECKE G, PETERS MC. The restoration of endodontically treated, single-rooted teeth with cast or direct posts and cores: a systematic review. J Prosthet Dent. 2002, vol 87, p. 380-386. https://doi.org/10.1067/mpr.2002.123848.

[27] IBBESTON R. Clinical considerations for adhesive bridge-work. Dent Update. 2004, vol 31, p. 254-260. https://doi.org/10.12968/denu.2004.31.5.254.

[28] KASSARDIJIAN V, VARMA S, ANDIAPPAN M, CREUGERS NH, BARTLETT D. A systematic review and meta-analysis of the longevity of anterior and posterior all-ceramic crowns. J Dent. 2016, vol 55, p. 1-6. https://doi.org/10.1016/j.jdent.2016.08.009.

[29] KERN M. Clinical long-term survival of two-retainer and single-retainer all-ceramic resin-bonded fixed partial dentures. Quintessence Int. 2005, vol 36, p. 141-147.

[30] KIMMICH M, STAPPERT CFJ. Intraoral treatment of veneering porcelain chipping of fixed dental restorations. The Journal of the American Dental Association. 2013, vol 144(1), p. 31-44. https://doi.org/10.14219/jada.archive.2013.0011.

[31] KOENIG V, VANHEUSDEN AJ, LE GOFF SO, MAINJOT AK. Clinical risk factors related to failures with zirconia-based restorations: an up to 9-year retrospective study. J Dent. 2013, vol 41, p. 1164-1174. https://doi.org/10.1016/j.jdent.2013.10.009.

[32] KRAMER N, KUNZELMANN KH, TASCHNER M, MEHL A, GARCIA-GODOY F, FRANKENBERGER R. Antagonist enamel wears more than ceramic inlays. J Dent Res. 2006, vol 85, p. 1097-1100. https://doi.org/10.1177/154405910608501206.

[33] MAROULAKOS G, THOMPSON GA, KONTOGIORGOS ED. Effect of cement type on the clinical performance and complications of zirconia and lithium disilicate tooth-supported crowns: A systematic review. J Prosthet Dent. 2018, vol 121(5), p. 754-765. https://doi.org/10.1016/j.prosdent.2018.10.011.

[34] MOHER D, LIBERATI A, TETZLAFF J, ALTMAN DG; THE PRISMA GROUP. Preferred reporting items for systematic reviews and metaanalyses: the PRISMA statement. PLoS Med. 2009 Jul 21; 6(7):e1000097. https://doi.org/10.1371/journal.pmed.1000097.

[35] MURAD MH, ASI N, ALSAWAS M, ALAHDAB ET AL. New evidence pyramid. BMJ Evidence-Based Medicine. 2016, vol 21, p. 125-127. https://doi.org/10.1136/ebmed-2016-110401.

[36] PANG Z, CHUGHTAI A, SAILER I, ZHANG Y. A fractographic study of clinically retrieved zirconia-ceramic and metal-ceramic fixed dental prostheses. Dent Mater. 2015, vol 31(10), p. 1198-1206. https://doi.org/10.1016/j.dental.2015.07.003.

[37] PAPADIOCHOU S, PISSIOTIS AL. Marginal adaptation and CAD-CAM technology: a systematic review of restorative material and fabrication techniques. J Prosthet Dent. 2018, vol 119, p. 545-551. https://doi.org/10.1016/j.prosdent.2017.07.001.

[38] PJETURSSON BE, SAILER I, MAKAROV NA, ZWAHLEN M, THOMA DS. All-ceramic or metal-ceramic tooth-supported fixed dental prostheses (FDPs)? A systematic review of the survival and complication rates. Part II: Multiple-unit FDPs. Dent Mater. 2015, vol 31(6), p. 624-639. https://doi.org/10.1016/j.dental.2015.02.013.

[39] PJETURSSON BE, SAILER I, MAKAROV NA, ZWAHLEN M, THOMA DS. Corrigendum to "All-ceramic or metal-ceramic tooth-supported fixed dental prostheses (FDPs)? A systematic review of the survival and complication rates. Part II: Multiple-unit FDPs"' [Dental Materials 31 (6) (2015) 624-639]. Dent Mater. 2017, vol 33(1): e48-e51. https://doi.org/10.1016/j.dental.2016.09.033.

[40] PJETURSSON BE, TAN WC, TAN K, BRAGGER U, ZWAHLEN M, LANG NP, A systematic review of the survival and complication rates of resin-bonded bridges after an observation period of at least 5 years. Clin Oral Implants Res. 2002, vol 19, p. 131-141. https://doi.org/10.1111/j.16000501.2007.01527.x.

[41] RAIGRODSKI AJ, YU A, CHICHE GJ, HOCHSTEDLER JL, MANCL LA, MOHAMED SE. Clinical efficacy of veneered zirconium dioxidebased posterior partial fixed dental prostheses: five-year results. J Prosthet Dent. 2012, vol 108(4), p. 214-222. https://doi.org/10.1016/S00223913(12)60165-6.

[42] RODRIGUES SB, FRANKEN P, CELESTE RK, LEITUNE VCB, COLLARES FM. CAD/CAM or conventional ceramic materials restorations longevity: a systematic review and meta-analysis. Journal of Prosthodontic Research. 2019, vol. 63(4), p. 389-395. https://doi.org/10.1016/j.jpor.2018.11.006.

[43] SAILER I, BALMER M, HUSLER J, HAMMERLE CHF, KANEL S, THOMA DS. 10-year randomized trial (RCT) of zirconia-ceramic and metalceramic fixed dental prostheses. J Dent. 2018, vol. 76, p. 32-39. https://doi.org/10.1016/j.jdent.2018.05.015.

[44] SAILER I, GOTTNERB J, KANELB S, HAMMERLE CH. Randomized controlled clinical trial of zirconia-ceramic and metal-ceramic posterior fixed dental prostheses: a 3-year follow-up. Int J Prosthodont. 2009, vol 22, p. 553-560.

[45] SAILER I, MAKAROV NA, THOMA DS, ZWAHLEN M, PJETURSSON BE. All-ceramic or metal-ceramic tooth-supported fixed dental prostheses (FDPs)? A systematic review of the survival and complication rates. Part I: Single crowns (SCs). Dent Mater. 2015, vol 31(6), p. 603-623. https://doi.org/10.1016/j.dental.2015.02.011.

[46] SAILER I, MAKAROV NA, THOMA DS, ZWAHLEN M, PJETURSSON BE. Corrigendum to "All-ceramic or metal-ceramic tooth-supported fixed dental prostheses (FDPs)? A systematic review of the survival and complication rates. Part I: Single crowns (SCs)'” [Dental Materials 31 (6) (2015) 603-623]. Dent Mater. 2016, vol 32(12): e389-e390. https://doi.org/10.1016/j.dental.2016.09.032.

[47] SALMI LR. Lecture critique et communication médicale scientifique. Comment lire, présenter, rédiger et publier une étude clinique ou épidémiologique. 3e édition. Issy-les-Moulineaux (France) : Elsevier Masson ; 2012.

[48] SARKIS-ONFORE R, JACINTO R, BOSCATO N, CENCI MS, PEREIRA-CENCI T. Cast metal vs. glass fibre posts: a randomized controlled trial with up to 3 years of follow up. J Dent. 2014, vol. 42(5), p. 582-587. https://doi.org/10.1016/j.jdent.2014.02.003.

[49] SCHLEY JS, HEUSSEN N, REICH S, FISCHER J, HASELHUHN K, WOLFART S. Survival probability of zirconia-based fixed dental prostheses up to 5 yr: a systematic review of the literature. Eur J Oral Sci. 2010, vol 118(5), p. 443-450. https://doi.org/10.1111/j.1600-0722.2010.00767.x.

[50] SKUPIEN JA, CENCI MS, OPDAM NJ, KREULEN CM, HUYSMANS MC, PEREIRA-CENCI T. Crown vs composite for post-retained restorations: an up to 5 years RCT. J Dent. 2016, vol 48(6), p. 34-39. https://doi.org/10.1016/j.jdent.2016.03.007.

[51] SOARES LM, SOARES C, MIRANDA ME, BASTING RT. Influence of Core-Veneer thickness ratio on the fracture load and failure mode of zirconia crowns. J Prosthodont. 2019, vol 28(2), p. 209-215. https://doi.org/10.1111/jopr.12601.

[52] STEFANESCU C, IONITA C, NECHITA V, DRAFTA S, OANCEA L, PETRE A. Survival Rates and Complications for Zirconia-Based Fixed Dental Prostheses in a Period up to 10 Years: A Systematic Review. Eur J Prosthodont Restor Dent. 2018, vol 26(2), p. 54-61.

[53] SWAIN MV. Unstable cracking (chipping) of veneering porcelain on all-ceramic dental crowns and fixed partial dentures. Acta Biomater. 2009, vol 5, p. 1668-1667. https://doi.org/10.1016/j.actbio.2008.12.016. 
[54] THOMA DS, SAILER I, IOANNIDIS A, ZWAHLEN M, MAKAROV N, PJETURSSON BE. A systematic review of the survival and complication rates of resin-bonded fixed dental prostheses after a mean observation period of at least 5 years. Clin Oral Implants Res. 2017, vol 28(11), p. 14211432. https://doi.org/10.1111/clr.13007.

[55] TORBJORNER A, FRANSSON B. A literature review on the prosthetic treatment of structurally compromised teeth. Int J Prosthodont. 2004, vol 17, p. 369-376.

[56] WYATT CC. Resin-bonded fixed partial dentures: what's new? J Can Dent Assoc. 2007, vol 73, p. $933-938$. 